Alloys and Compounds

Elsevier Editorial System(tm) for Journal of

Manuscript Draft

Manuscript Number:

Title: Investigation of lanthanum substitution effects in yttrium aluminium garnet: Importance of solid state NMR and EPR methods

Article Type: Full Length Article

Keywords: yttrium aluminium garnet, lanthanum, substitution effect, solgel processing, properties

Corresponding Author: Professor Aivaras Kareiva, PhD

Corresponding Author's Institution: Vilnius University

First Author: Andrius Laurikenas

Order of Authors: Andrius Laurikenas; Danas Sakalauskas; Arunas Marsalka; Rimantas Raudonis; Andris Antuzevics; Vytautas Balevicius; Aleksej

Zarkov; Aivaras Kareiva, PhD

Abstract: In this study yttrium aluminium garnet (YAG) specimens in which yttrium was partially substituted by lanthanum Y3-xLaxAl5012 (YLaAG) were prepared by an aqueous sol-gel method. The resulting sol was concentrated by slow solvent evaporation at $65 \mathrm{oC}$. The obtained gels were dried in an oven at 120 oc for $24 \mathrm{~h}$. The obtained precursor gel powders were calcined at $800 \mathrm{OC}$ and $1000 \mathrm{OC}$ in air. YLaAG samples were analyzed by X-ray diffraction (XRD), solid state nuclear magnetic resonance (NMR), scanning electron microscopy (SEM) and electron paramagnetic resonance (EPR) methods. Luminescence measurements of YLaAG samples were also recorded. The XRD analysis results showed that only low substitution of yttrium by lanthanum is possible in Y3-xLaxAl5012 without destroying garnet crystal structure. It was also demonstrated in this study, that solid state NMR and EPR methods are indispensable tools for the explanation of processes and properties observed in the newly synthesized Y3-xLaxAl5012 compounds. 


\section{Department of Inorganic Chemistry Faculty of Chemistry and Geosciences Vilnius University}

8 August 2020

\section{Editor}

Journal of Alloys and Compounds

Dear Editor,

In this my letter I enclose the manuscript by A. Laurikenas, D. Sakalauskas, A. Marsalka, R. Raudonis, A. Antuzevics, V. Balevicius, A. Zarkov, A. Kareiva "Investigation of lanthanum substitution effects in yttrium aluminium garnet: Importance of solid state NMR and EPR methods".

I hope very much that you will find the results presented in this manuscript interesting to publish in Journal of Alloys and Compounds.

I am looking forward to hearing from you.

Sincerely yours,

Prof. Aivaras Kareiva

Director of Institute of Chemistry

Naugarduko 24

LT-03225 Vilnius

Lithuania
Tel.: 370-5-2193110; Fax: 370-5-2330987

E-mail: aivaras.kareiva@chgf.vu.lt 
In this study yttrium aluminium garnet (YAG) specimens in which yttrium was partially substituted by lanthanum $\mathrm{Y}_{3-\mathrm{x}} \mathrm{La}_{\mathrm{x}} \mathrm{Al}_{5} \mathrm{O}_{12}$ ( $\mathrm{YLaAG}$ ) were prepared by an aqueous sol-gel method. The resulting sol was concentrated by slow solvent evaporation at $65{ }^{\circ} \mathrm{C}$. The obtained gels were dried in an oven at $120{ }^{\circ} \mathrm{C}$ for $24 \mathrm{~h}$. The obtained precursor gel powders were calcined at $800{ }^{\circ} \mathrm{C}$ and $1000{ }^{\circ} \mathrm{C}$ in air. YLaAG samples were analyzed by X-ray diffraction (XRD), solid state nuclear magnetic resonance (NMR), scanning electron microscopy (SEM) and electron paramagnetic resonance (EPR) methods. Luminescence measurements of YLaAG samples were also recorded. The XRD analysis results showed that only low substitution of yttrium by lanthanum is possible in $\mathrm{Y}_{3-\mathrm{x}} \mathrm{La}_{\mathrm{x}} \mathrm{Al}_{5} \mathrm{O}_{12}$ without destroying garnet crystal structure. It was also demonstrated in this study, that solid state NMR and EPR methods are indispensable tools for the explanation of processes and properties observed in the newly synthesized $\mathrm{Y}_{3-\mathrm{x}} \mathrm{La}_{\mathrm{x}} \mathrm{Al}_{5} \mathrm{O}_{12}$ compounds. 


\title{
Investigation of lanthanum substitution effects in yttrium aluminium garnet: Importance of solid state NMR and EPR methods
}

\author{
A. Laurikenas ${ }^{1}$, D. Sakalauskas ${ }^{1}$, A. Marsalka ${ }^{2}$, R. Raudonis ${ }^{1}$, A. \\ Antuzevics $^{3}$, V. Balevicius ${ }^{2}$, A. Zarkov ${ }^{1}$, A. Kareiva ${ }^{1, *}$ \\ ${ }^{1}$ Institute of Chemistry, Vilnius University, Naugarduko 24, LT-03225 Vilnius, Lithuania \\ 03225, Vilnius, Lithuania \\ ${ }^{2}$ Institute of Chemical Physics, Faculty of Physics, Vilnius University, Sauletekio al. 3, LT- \\ 10257 Vilnius, Lithuania \\ ${ }^{3}$ Institute of Solid State Physics, University of Latvia, Kengaraga 8, LV-1063 Riga, Latvia
}

\begin{abstract}
In this study yttrium aluminium garnet (YAG) specimens in which yttrium was partially substituted by lanthanum $\mathrm{Y}_{3-\mathrm{x}} \mathrm{La}_{\mathrm{x}} \mathrm{Al}_{5} \mathrm{O}_{12}$ (YLaAG) were prepared by an aqueous sol-gel method. The resulting sol was concentrated by slow solvent evaporation at $65{ }^{\circ} \mathrm{C}$. The obtained gels were dried in an oven at $120{ }^{\circ} \mathrm{C}$ for $24 \mathrm{~h}$. The obtained precursor gel powders were calcined at $800{ }^{\circ} \mathrm{C}$ and $1000{ }^{\circ} \mathrm{C}$ in air. YLaAG samples were analyzed by $\mathrm{X}$-ray diffraction (XRD), solid state nuclear magnetic resonance (NMR), scanning electron microscopy (SEM) and electron paramagnetic resonance (EPR) methods. Luminescence measurements of YLaAG samples were also recorded. The XRD analysis results showed that only low substitution of yttrium by lanthanum is possible in $\mathrm{Y}_{3-\mathrm{x}} \mathrm{La}_{\mathrm{x}} \mathrm{Al}_{5} \mathrm{O}_{12}$ without destroying garnet crystal structure. It was also demonstrated in this study, that solid state NMR and EPR methods are indispensable tools for the explanation of processes and properties observed in the newly synthesized $\mathrm{Y}_{3-\mathrm{x}} \mathrm{La}_{\mathrm{x}} \mathrm{Al}_{5} \mathrm{O}_{12}$ compounds.
\end{abstract}

Keywords: yttrium aluminium garnet, lanthanum, substitution effect, sol-gel processing, properties

Corresponding author: aivaras.kareiva@chgf.vu.lt 


\section{Introduction}

Yttrium and lanthanide aluminium garnets $\left(\mathrm{Y}_{3} \mathrm{Al}_{5} \mathrm{O}_{12}, \mathrm{YAG}\right.$ and $\mathrm{Ln}_{3} \mathrm{Al}_{5} \mathrm{O}_{12}, \mathrm{LnAG}, \mathrm{Ln}-$ lanthanide element from $\mathrm{Eu}$ to $\mathrm{Lu}$ ) show great chemical stability, high temperature creep resistance and extremely important luminescent properties [1-6]. However, during the preparation of YAG very often the formation of secondary phases like perovskite $\left(\mathrm{YAlO}_{3}\right.$, YAP) and hexagonal aluminate $\left(\mathrm{YAlO}_{3}, \mathrm{YAH}\right)$ have been observed [7, 8]. The sol-gel techniques have been used to prepare a variety of mixed-metal oxides including garnet materials with excellent phase purity of the final product [9-13].

Several lanthanide aluminium garnets (i.e., $\mathrm{La}_{3} \mathrm{Al}_{5} \mathrm{O}_{12}, \mathrm{Ce}_{3} \mathrm{Al}_{5} \mathrm{O}_{12}, \mathrm{Pr}_{3} \mathrm{Al}_{5} \mathrm{O}_{12}, \mathrm{Nd}_{3} \mathrm{Al}_{5} \mathrm{O}_{12}$, $\mathrm{Sm}_{3} \mathrm{Al}_{5} \mathrm{O}_{12}$ ) has not been synthesized so far, to the best our knowledge. A sol-gel method based on in-situ generation of mixed-metal chelates by complexing metal ions with ethane1,2-diol in an aqueous media has been used to prepare lanthanide-ion containing garnets, $\mathrm{Ce}_{3} \mathrm{Al}_{5} \mathrm{O}_{12}, \mathrm{Pr}_{3} \mathrm{Al}_{5} \mathrm{O}_{12}$, and $\mathrm{Nd}_{3} \mathrm{Al}_{5} \mathrm{O}_{12}$ [14]. It was concluded from the XRD data that during annealing of Ce-Al-O, Pr-Al-O and Nd-Al-O precursor gels at $800-1200{ }^{\circ} \mathrm{C}$ the garnet structure compounds did not form. The samples consisted of cerium oxide $\left(\mathrm{CeO}_{2}\right)$ and alumina $\left(\mathrm{Al}_{2} \mathrm{O}_{3}\right)$ phases, or the formation of praseodymium and neodymium perovskite aluminates $\left(\mathrm{NdAlO}_{3}, \mathrm{PrAlO}_{3}\right)$ and $\mathrm{Al}_{2} \mathrm{O}_{3}$ phases instead of single phase garnets took place. The monophasic $\mathrm{Y}_{3-\mathrm{x}} \mathrm{Nd}_{\mathrm{x}} \mathrm{Al}_{5} \mathrm{O}_{12}$ garnet has been obtained when $\mathrm{x}$ ranged from 0.1 to 0.8 [15]. The monophasic $\mathrm{Sm}_{3} \mathrm{Al}_{5} \mathrm{O}_{12}$ garnet phase is not synthesized and characterized so far as well [16]. However, during the heat treatment of the La-Al-O precursor gel powders at the same temperatures the $\mathrm{LaAlO}_{3}: \mathrm{Al}_{2} \mathrm{O}_{3}$ or $\mathrm{LaAlO}_{3}: \mathrm{La}_{2} \mathrm{O}_{3}: 2 \mathrm{Al}_{2} \mathrm{O}_{3}$ mixtures instead of the single $\mathrm{La}_{3} \mathrm{Al}_{5} \mathrm{O}_{12}$ garnet phase have formed $[17,18]$. The main aim of this study was for the first time to investigate lanthanum substitution effects in $\mathrm{Y}_{3-\mathrm{x}} \mathrm{La}_{\mathrm{x}} \mathrm{Al}_{5} \mathrm{O}_{12}$ garnet using mainly $\mathrm{XRD}$, NMR and EPR characterization methods.

\section{Experimental}

\subsection{Synthesis}


Yttrium aluminium garnet powders substituted by lanthanum $\mathrm{Y}_{3-\mathrm{x}} \mathrm{La}_{\mathrm{x}} \mathrm{Al}_{5} \mathrm{O}_{12}(\mathrm{x}=0.03$, $0.015,0.30,0.45,0.60,0.75,1.0$ and 1.5$)$ were synthesized using an aqueous sol-gel processing. In the aqueous sol-gel process, the following materials were used: $\mathrm{Y}_{2} \mathrm{O}_{3}(99.99 \%$, Aldrich), $\mathrm{La}_{2} \mathrm{O}_{3}\left(99.99 \%\right.$, Aldrich), $\mathrm{Al}\left(\mathrm{NO}_{3}\right)_{3} \cdot 9 \mathrm{H}_{2} \mathrm{O}$ (99.99\%, Aldrich), acetic acid (99.5\%, Chempur) and ethane-1,2-diol (99\%, Merck). $\mathrm{Y}_{2} \mathrm{O}_{3}$ was dissolved firstly in $0.2 \mathrm{M}$ acetic acid (100 ml). Clear solution was obtained after stirring at $60-65^{\circ} \mathrm{C}$ for $10 \mathrm{~h}$ in beaker covered with a watch-glass. Then, aqueous solution of aluminium nitrate nonahydrate $(25 \mathrm{ml})$ was added to the yttrium acetate solution. The mixture was stirred at the same temperature for $1 \mathrm{~h}$ and solution of and lanthanum acetate $\left(\mathrm{La}_{2} \mathrm{O}_{3}\right.$ dissolved in $0.2 \mathrm{M}$ acetic acid) was added. The resulting mixture was stirred at $60-65^{\circ} \mathrm{C}$ for $1 \mathrm{~h}$, followed by drop-wise addition of ethane1,2-diol ( $2 \mathrm{ml}$ ) upon vigorous stirring. The resulting sols were stirred at the same temperature for another $1 \mathrm{~h}$ and then concentrated by slow solvent evaporation at $65^{\circ} \mathrm{C}$ until they turned into transparent gels. The gels were dried in an oven at $100-110{ }^{\circ} \mathrm{C}$ for $24 \mathrm{~h}$. The resulting gel powders were ground in an agate mortar and heated in air at $800{ }^{\circ} \mathrm{C}$ for $5 \mathrm{~h}$ by slow temperature elevation $\left(3^{\circ} \mathrm{C} \min ^{-1}\right)$. After grinding in an agate mortar, the powders were further sintered in air at $1000{ }^{\circ} \mathrm{C}$ for $10 \mathrm{~h}$.

\subsection{Characterization}

X-ray diffraction analysis (XRD) was performed on a Rigaku MiniFlex diffractometer using $\mathrm{Cu} \mathrm{K}_{\alpha}$ radiation $\left(1.541874 \AA\right.$ ). The solid state ${ }^{27} \mathrm{Al}$ MAS NMR experiments were performed using $400 \mathrm{MHz}$ Bruker AVANCE III HD spectrometer with a $4 \mathrm{~mm}$ wide bore double resonance HX CP-MAS probe. The experiments were performed in $9.4 \mathrm{~T}$ magnetic field using Ascend wide bore superconducting magnet. The Larmor frequency for ${ }^{27} \mathrm{Al}$ was 104.3 MHz. ${ }^{27} \mathrm{Al}$ chemical shifts were determined respect to the narrow peak of 6-coordinated $\mathrm{Al}$ in the non-doped YAG. This signal has the chemical shift very close to that of $1 \mathrm{M}$ $\mathrm{Al}\left(\mathrm{NO}_{3}\right)_{3}$ that is traditionally used for the referencing of ${ }^{27} \mathrm{Al}$ NMR spectra $[19,20]$. The MAS frequency was set $10 \mathrm{kHz} .{ }^{27} \mathrm{Al}$ MAS spectra were measured applying the single pulse- 
acquire pulse sequence using the short duration ( $3 \mathrm{~ms}$ ) excitation pulse, which corresponds to the excitation bandwidth of $83 \mathrm{kHz}$. The number of scans was 800 and the relaxation delay was $1 \mathrm{~s}$. Scanning electron microscopy (SEM) micrographs were obtained with Hitachi SU-70 SEM. Luminescence measurements were performed using Edinburgh Instruments FLS980 spectrometer equipped with double excitation and emission monochromators, $450 \mathrm{Xe}$ arc lamp, mirror optics for powder samples. Using $280 \mathrm{~nm}$ excitation wavelength for emission spectra, while excitation spectra were measured for $325 \mathrm{~nm}$ wavelength. Quantitative elemental analysis of the samples was performed using Perkin Elmer Optima 7000DV inductively coupled plasma optical emission spectrometer (ICP-OES). The analyzed powders were dissolved in nitric acid $\left(\mathrm{HNO}_{3}\right.$, Rotipuran ${ }^{\circledR}$ Supra $69 \%$, Carl Roth) and diluted with deionized water. Low temperature $(20 \mathrm{~K})$ electron paramagnetic resonance $(\mathrm{EPR})$ spectra were measured with Bruker ELEXSYS-II E500 CW-EPR spectrometer equipped with liquid helium flow cryostat. Microwaves were generated at $0.2 \mathrm{~mW}$ power and $9.36 \mathrm{GHz}$ frequency; the magnetic field modulation parameters were set at $100 \mathrm{kHz}$ and $1 \mathrm{mT}$. EPR spectra simulations have been performed in EasySpin [21].

\section{Results and Discussion}

The XRD patterns of the $\mathrm{Y}_{3-\mathrm{x}} \mathrm{La}_{\mathrm{x}} \mathrm{Al}_{5} \mathrm{O}_{12}$ samples having different substitution level of lanthanum are presented in Fig. 1. These XRD results revealed that the phase purity of $\mathrm{Y}_{3-}$ ${ }_{x} \mathrm{La}_{\mathrm{x}} \mathrm{Al}_{5} \mathrm{O}_{12}$ specimens depends on the amount of lanthanum introduced to the garnet structure instead of yttrium. Evidently, the obtained $\mathrm{XRD}$ patterns for $\mathrm{Y}_{3} \mathrm{Al}_{5} \mathrm{O}_{12}$ and for the $\mathrm{Y}_{3-}$ ${ }_{x} \mathrm{La}_{\mathrm{x}} \mathrm{Al}_{5} \mathrm{O}_{12}$ with $\mathrm{x}=0.03,0.015$ and 0.30 are in a good agreement with the reference data (ISCD 00-033-0040) and correspond to the single phase YAG or YLaAG. The lattice parameter $a$ and cell volume $V$ of these samples monotonically increased from $a=12.012 \AA$ and $V=1733.2 \AA$ (for $\mathrm{x}=0$ ) till $a=12.160 \AA$ and $V=1798.1 \AA$ (for $\mathrm{x}=0.30$ ) confirming that slightly larger lanthanum ion substitutes yttrium ion in the garnet structure. However, the 
XRD patterns of $\mathrm{Y}_{3-\mathrm{x}} \mathrm{La}_{\mathrm{x}} \mathrm{Al}_{5} \mathrm{O}_{12}$ with higher substitutional level of lanthanum $(\mathrm{x}=0.45$ and 0.60) reveal that along with YLaAG phase the perovskite $\mathrm{YAlO}_{3}$ and $\mathrm{LaAlO}_{3}$ crystalline phases have formed after the heat-treatment of $\mathrm{Y}(\mathrm{La})-\mathrm{Al}-\mathrm{O}$ gel precursors at $1000{ }^{\circ} \mathrm{C}$. These results evidently show the possibility for full substitution of $\mathrm{Y}^{3+}$ by $\mathrm{La}^{3+}$ in YAG crystal structure at low concentration of samarium (up to $\sim 10 \%$ ). Interestingly, with further increasing substitutional level of lanthanum in $\mathrm{Y}_{3-\mathrm{x}} \mathrm{La}_{\mathrm{x}} \mathrm{Al}_{5} \mathrm{O}_{12}(\mathrm{x}=0.75,1.0$ and 1.50) the formation only perovskite phases could be detected. No even traces of YAG or YLaAG compounds have formed. Thus, the reactions (2-5) instead of the reaction (1) possibly proceeds at highest substitutional concentration of lanthanum.

$$
\begin{gathered}
1.5 \mathrm{Y}_{2-\mathrm{x}} \mathrm{La}_{\mathrm{x}} \mathrm{O}_{3}+2.5 \mathrm{Al}_{2} \mathrm{O}_{3} \rightarrow \mathrm{Y}_{3-1.5 \mathrm{x}} \mathrm{La}_{1.5 \mathrm{x}} \mathrm{Al}_{5} \mathrm{O}_{12} \\
1.5 \mathrm{La}_{2} \mathrm{O}_{3}+2.5 \mathrm{Al}_{2} \mathrm{O}_{3} \rightarrow \mathrm{LaAlO}_{3}+\mathrm{La}_{2} \mathrm{O}_{3}+2 \mathrm{Al}_{2} \mathrm{O}_{3} \\
1.5 \mathrm{Y}_{2} \mathrm{O}_{3}+2.5 \mathrm{Al}_{2} \mathrm{O}_{3} \rightarrow \mathrm{YAlO}_{3}+\mathrm{Y}_{2} \mathrm{O}_{3}+2 \mathrm{Al}_{2} \mathrm{O}_{3} \\
1.5 \mathrm{La}_{2} \mathrm{O}_{3}+2.5 \mathrm{Al}_{2} \mathrm{O}_{3} \rightarrow 3 \mathrm{LaAlO}_{3}+\mathrm{Al}_{2} \mathrm{O}_{3} \\
1.5 \mathrm{Y}_{2} \mathrm{O}_{3}+2.5 \mathrm{Al}_{2} \mathrm{O}_{3} \rightarrow 3 \mathrm{YAlO}_{3}+\mathrm{Al}_{2} \mathrm{O}_{3}
\end{gathered}
$$

The most likely that side phases formed during synthesis are perovskites (ISCD 00-029-0083) and alumina (ISCD 00-046-1212). However, no traces of $\mathrm{Al}_{2} \mathrm{O}_{3}$ could be detected from XRD patterns. These results let us to predict that amorphous alumina has formed even during the synthesis at such high temperature. A broad variety of solid-state NMR techniques, such as ${ }^{27}$ Al MAS, multiple quantum magic angle spinning (MQ-MAS), etc., have been effectively applied elucidating very fine structural details in series ions-doped aluminates [19, 20, 22].

Therefore in the present work the ${ }^{27} \mathrm{Al}$ MAS NMR spectroscopy was applied in order to elucidate the influence of the gradual La-doping on the structural changes of $\mathrm{Y}_{3} \mathrm{Al}_{5} \mathrm{O}_{12}$ garnet. The spectra are shown in Fig. 2. It is well-known that the ${ }^{27} \mathrm{Al}$ chemical shifts are strongly caused by the structural environments of aluminium atoms, i.e. the nearest-neighbour coordination geometry. Therefore the ${ }^{27} \mathrm{Al}$ MAS NMR spectra provide useful, sometimes even unique information on the Al sites and the coordination numbers. According literature data [19, 
$20,22]$ it can be stated that in the most $\mathrm{Al}-\mathrm{O}$ environments, the ${ }^{27} \mathrm{Al}$ NMR peaks of 6coordinated $\mathrm{Al}^{\mathrm{VI}}\left(\mathrm{AlO}_{6}\right)$ appear in the range covering -20 to $+15 \mathrm{ppm}$ and are well separated from the signals from the 4-coordinated $\mathrm{Al}^{\mathrm{IV}}\left(\mathrm{AlO}_{4}\right)$ that appear at 50 to $145 \mathrm{ppm}$. It is also known that the signals of 5 -coordinated $\mathrm{Al}^{\mathrm{V}}\left(\mathrm{AlO}_{5}\right)$ can appear in the range +15 to $+35 \mathrm{ppm}$. However, these signals were observed rather rarely, e.g. in the glassy YAG-4Si [23] or in the pristine and Eu-doped and Dy-co-doped $\mathrm{SrAl}_{4} \mathrm{O}_{7}$ [22]. In the last work this was attributed to certain phase imperfections that, most probably, as the amorphous/glassy domains may appear. Also note that a certain polemic around the existence and the detection of the ${ }^{27} \mathrm{Al}$ NMR signals from $\mathrm{AlO}_{5}$ sites run in the literature [24-26].

The peaks of 4- and 6-coordinated Al are well resolved and easily recognized in the studied spectra. The four-coordinated $\mathrm{Al}^{\mathrm{IV}}$ atoms are surrounded by two yttrium ions at a distance of about 3.0 $\AA$, and by additional four yttrium ions at about $3.7 \AA$ [19]. This gives rise to a relatively large electric field gradient at the position of $\mathrm{Al}^{\mathrm{IV}}$ nuclei and to a broad complex shaped peak due to much stronger quadrupolar effects. The six-coordinated $\mathrm{Al}^{\mathrm{VI}}$ atoms reside in a much more symmetrical environment. They are surrounded by six equidistant yttrium ions at a distance of 3.35 $\AA$. This causes a smaller value for the electric field gradient, and as a result, the $\mathrm{Al}^{\mathrm{VI}}$ peaks are narrower and rather symmetrical in shape (Fig. 2). In the case of $\mathrm{Y}_{3-\mathrm{x}} \mathrm{La}_{\mathrm{x}} \mathrm{Al}_{5} \mathrm{O}_{12}$ series is that the resonance frequencies of ${ }^{27} \mathrm{Al}$ nuclei that are close to the $\mathrm{La}^{3+}$ substituent ions are shifted to higher values compared to the resonance frequency of ${ }^{27} \mathrm{Al}$ nuclei that have only $\mathrm{Y}^{3+}$ ions nearby. As in the earlier studied case of $\mathrm{Sm}^{3+}$ substitutions [20] it can be supposed this is due to a through-bond hyperfine interaction and through-space anisotropic dipolar interaction between the unpaired $4 \mathrm{f}$ electronic spins of the substituents and the ${ }^{27} \mathrm{Al}$ nuclear spins. Beside two major signals at 68 ppm and 0 ppm that belong to four- and six-coordinated aluminium atoms surrounded by yttrium (denoted as $\mathrm{Y}-\mathrm{Al}^{\mathrm{IV}}$ and $\mathrm{Y}-\mathrm{Al}^{\mathrm{VI}}$ ), the additional peaks at $73 \mathrm{ppm}$ and $9 \mathrm{ppm}$ are observed in the ${ }^{27} \mathrm{Al}$ MAS NMR spectra. The latter two peaks can be assigned respectively to $\mathrm{Al}^{\mathrm{IV}}$ and $\mathrm{Al}^{\mathrm{VI}}$ atoms in their first coordination shells of $\mathrm{La}^{3+}$ cations $\left(\mathrm{La}-\mathrm{Al}^{\mathrm{IV}}\right.$ and $\left.\mathrm{La}-\mathrm{Al}^{\mathrm{VI}}\right)$, 
respectively. The intensity of $\mathrm{Al}^{\mathrm{VI}}$ peak with $\mathrm{La}^{3+}$ in their vicinity increases with an increasing $\mathrm{x}$ (Fig. 2). For more precise treatment the integral intensities were calculated using the multiple Voigt profile fitting of the overlapping signal contours. This can be used monitoring the structural evolution in the $\mathrm{Y}_{3-\mathrm{x}} \mathrm{La}_{\mathrm{x}} \mathrm{Al}_{5} \mathrm{O}_{12}$ series increasing the amount of the doping element. It is known that the 4-coordinated Al sites do not exist in the perovskite phase [27]. Then the onset of structural transformation, the region coexisting phases, the appearance of perovskite-like phase and the residual of YAG phase can be deduced (Fig. 3).

Fig. 4 shows the representative SEM micrographs of sol-gel derived and annealed at $1000{ }^{\circ} \mathrm{C} \mathrm{Y}_{3-\mathrm{x}} \mathrm{La}_{\mathrm{x}} \mathrm{Al}_{5} \mathrm{O}_{12}$ specimens having different amount of La. Evidently, the morphologies of obtained materials lack uniformity, as could be observed for the microstructures of compounds synthesized by sol-gel method [28]. On the other hand, some trends in changes of microstructure with changing concentration of lanthanum could be observed. The SEM micrographs taken for the samples with lower amount of $\mathrm{La}^{3+}$ ions $(\mathrm{x} \leq$ 0.3) show the formation of differently shaped micro-sized $(2-10 \mu \mathrm{m})$ particles forming large agglomerates $(50-80 \mu \mathrm{m})$. Even larger agglomerates have formed with increasing amount of lanthanum till $\mathrm{x}=0.6$. The SEM micrographs of the samples with highest substitutional level of $\mathrm{La}^{3+}(\mathrm{x}>0.6)$ showed the formation of plate-like crystals $(30-100 \mu \mathrm{m})$ and monoliths. Moreover, these monoliths are partially covered with small particles. Thus, the SEM results seem to be in a good agreement with XRD analysis results.

It is known that the lanthanum cannot act as center of the luminescence, since $\mathrm{La}^{3+}$ possesses a relatively stable empty $4 \mathrm{f}$ shell (the configuration is $4 \mathrm{f}^{0}$ ) [29]. According to Dieke diagram no emission line would fall in the visible region $[29,30]$. There are many reports that $\mathrm{La}^{3+}$ ions can be used to sensitize other lanthanide ions [31-33]. It was also recently shown that the luminescence of the $\mathrm{Bi}$-doped $\mathrm{La}_{2} \mathrm{MoO}_{6}$ phosphor is mainly related to the host lattice itself (molybdate) and distortions induced by La/Bi substitution [34]. Moreover, Freeda and Subash [35] observed contradictory $\mathrm{La}^{3+}$ photoluminescence at $395 \mathrm{~nm}$ and $535 \mathrm{~nm}$ in 
$\mathrm{CaAl}_{2} \mathrm{O}_{4}$ matrix. Therefore, we decided to investigate the possible luminescence properties of our synthesized $\mathrm{Y}_{3-\mathrm{x}} \mathrm{La}_{\mathrm{x}} \mathrm{Al}_{5} \mathrm{O}_{12}$ garnet samples.

Fig. 5 shows the excitation and emission spectra of $\mathrm{Y}_{3-\mathrm{x}} \mathrm{La}_{\mathrm{x}} \mathrm{Al}_{5} \mathrm{O}_{12}$ samples with different Y/La ratio. The excitation spectra for emission at $560 \mathrm{~nm}$ consist of two broad bands at about $450 \mathrm{~nm}$. These bands correspond to the $[\mathrm{Xe}] 4 \mathrm{f} \rightarrow[\mathrm{Xe}] 5 \mathrm{~d}$ transitions of $\mathrm{Ce}^{3+}$ ion $[36,37]$. As seen, the higher energy band is much weaker than its lower energy counterpart. This is probably caused by photoionization, i.e. the higher crystal-field component of the excited $[\mathrm{Xe}] 5 \mathrm{~d}^{1}$ configuration of $\mathrm{Ce}^{3+}$ is likely close or in the conduction band [37]. It was also observed that the intensity of low energy bands decreases with higher La content in the structure. This indicates that the crystal-field strength decreases with the increasing La content in the host lattice. The emission spectra under $450 \mathrm{~nm}$ excitation consist of a single broad bands peaked at around $560 \mathrm{~nm}$. The spectra comprise a broad band, which is due to two strongly overlapping bands from the lowest crystal-field component of the $[\mathrm{Xe}] 5 \mathrm{~d}^{1}$ configuration to the spin-orbit split sublevels ${ }^{2} \mathrm{~F}_{5 / 2}$ and ${ }^{2} \mathrm{~F}_{7 / 2}$ of the $[\mathrm{Xe}] 4 \mathrm{f}^{1}$ configuration of $\mathrm{Ce}^{3+}$ ions [38]. However, the observed emission maximum variation from 545 to $575 \mathrm{~nm}$ is not dependent on the amount of substituent. On the other hand, these photoluminescence results are in an agreement with the XRD results. The most intensive emission of $\mathrm{Ce}^{3+}$ was observed for the monophasic $\mathrm{Y}_{3-\mathrm{x}} \mathrm{La}_{\mathrm{x}} \mathrm{Al}_{5} \mathrm{O}_{12}$ specimens with $\mathrm{x}=0.03,0.015$ and 0.30 . For the YLaAG samples with higher amount of $\mathrm{La}(\mathrm{x}=0.45$ and 0.60$)$ the intensity of emission is abruptly decreases possibly due the changes of phase composition of the final synthesis product. Finally, when only perovskite phases have formed $(x=0.75,1.0$ and 1.50) the emission of $\mathrm{Ce}^{3+}$ is not observed anymore.

Thus, the $\mathrm{Ce}^{3+}$ emission was accidentally determined in the $\mathrm{Y}_{3-\mathrm{x}} \mathrm{La}_{\mathrm{x}} \mathrm{Al}_{5} \mathrm{O}_{12}$ samples. The question now is how cerium originated in the YLaAG garnet. As was mentioned the quantitative elemental analysis of the synthesized samples was performed using ICP-OES. Surprisingly, it was determined that lanthanum oxide which was used as lanthanum source 
contained about 5 ppm of cerium. The cerium was also detected in all $\mathrm{Y}_{3-\mathrm{x}} \mathrm{La}_{\mathrm{x}} \mathrm{Al}_{5} \mathrm{O}_{12}$ samples, and cerium amount was increased monotonically with increasing amount of lanthanum in the end products. In the single phase mixed-metal $\mathrm{Y}_{3-\mathrm{x}} \mathrm{La}_{\mathrm{x}} \mathrm{Al}_{5} \mathrm{O}_{12}$ garnets with $\mathrm{x}=0.03,0.015$ and 0.30 the amount of cerium varied in the range of $\sim 9.6 \cdot 10^{-6}-9.6 \cdot 10^{-7} \mathrm{~mol} \%$. Thus, even very low cerium impurities determined in the $\mathrm{Y}_{3-\mathrm{x}} \mathrm{La}_{\mathrm{x}} \mathrm{Al}_{5} \mathrm{O}_{12}$ garnet samples showed rather intensive luminescence. Recently, the $\left(\mathrm{Y}_{1-\mathrm{x}} \mathrm{Ce}_{\mathrm{x}}\right)_{3} \mathrm{Al}_{5} \mathrm{O}_{12}$ garnets with high $\mathrm{Ce}$ content $(\mathrm{x}=$ 0.006-0.21) were fabricated using a polymerized complex method via a two-step heating process [39]. Due to the higher amount of $\mathrm{Ce}^{3+}$ the emission peak in these garnets was shifted from 538.4 to $606.2 \mathrm{~nm}$ exhibiting orange-red emission. Despite the large lattice expansion of host crystal, crystal field splitting did not show a significant increase. Hence, the cerium emission in $\mathrm{Y}_{3-\mathrm{x}} \mathrm{La}_{\mathrm{x}} \mathrm{Al}_{5} \mathrm{O}_{12}$ samples probably could not be also explained by the change in crystal field splitting. On the other hand, variation of hues from green-yellow through yellow and eventually to orange in the $\mathrm{Y}_{3-\mathrm{x}} \mathrm{La}_{\mathrm{x}} \mathrm{Al}_{5} \mathrm{O}_{12}$ garnet samples with low concentration of cerium can be achieved, for example by co-doping [40].

EPR spectra of $\mathrm{Y}_{3-\mathrm{x}} \mathrm{La}_{\mathrm{x}} \mathrm{Al}_{5} \mathrm{O}_{12}$ garnet samples detected at $20 \mathrm{~K}$ are shown in Fig. 6. The spectra consist of a complex pattern of EPR signals in a broad magnetic field range, which is dependent on the amount of La doping. Field values, where YAG: $\mathrm{Ce}^{3+}$ resonances are expected [41-44], are indicated with the dashed lines. A more detailed analysis of the detected EPR signals is given in Fig. 7. The shape of the unmodified YAG sample spectrum in 0-0.6 T range is typical of $\mathrm{Fe}^{3+}$ impurities [45]. The high-spin state $S=5 / 2$ is the ground state for the $3 \mathrm{~d}^{5}$ configuration $\mathrm{Fe}^{3+}$ ion in the YAG matrix. Consequently, EPR transitions are determined by the Zeeman term as well as the second and fourth order zero field splitting terms of the spin Hamiltonian (SH), which in YAG powder spectrum is reflected by a signal which consists of multiple peaks in a broad field range. EPR signals of YAIG in octahedral and tetrahedral coordinations have been documented in the literature [46, 47]. Fig. 7 shows that even slight substitution with La produces broadening of the $\mathrm{Fe}^{3+}$ signal and at higher doping 
levels the signature peaks are no longer resolved. This indicates substitution-induced crystal lattice distortions, which produce variations in the $\mathrm{SH}$ parameter values.

The most notable feature in the EPR spectra of La modified samples in the 0.03-0.6 substitution range is appearance of peaks at $B \approx 0.24,0.36$ and $0.74 \mathrm{~T}$. This signal was observable only in the 5-40 $\mathrm{K}$ temperature range; at $60 \mathrm{~K}$ the signal had vanished. Such behaviour is typical for rare earth impurities and can be explained by rapid relaxation processes of the spin system at higher temperatures. The resonance positions can be approximated by an effective $\operatorname{spin} S^{*}=1 / 2$ system and a $\mathrm{SH}$ with orthorhombic symmetry:

$$
H=\mu_{B} B g S^{*}
$$

where $\mu_{B}$ is the Bohr magneton and $g$ is the $g$-tensor. The determined principal components of the $g$-tensor for the La0.03YAG sample are $g_{x}=2.750, g_{y}=1.860$ and $g_{z}=0.898$. These values are in a good agreement with the reported $g$ values of $2.74,1.87$ and 0.91 for $\mathrm{Ce}^{3+}$ in YAG single crystals [42-44]. Cerium ions reside in $D_{2}$ symmetry $\mathrm{Y}^{3+}$ sites of the YAG lattice $[42,43]$, which explains the low symmetry nature of the EPR spectrum.

A systematic shift and broadening of $\mathrm{Ce}^{3+}$ spectra features with increasing the La substitution level is visible in Fig. 6. EPR spectra simulations of the $g$-tensor values have been performed in order to account for these effects: the results are summarized in Table 1 . The shift of EPR resonance positions is reflected in the variations of the $g$ values, while $g$ strain parameters have been adjusted to reproduce experimental linewidths and relative intensities of spectral components. The "strains" contain information about the distribution of the respective SH parameter around its mean value due to site-to-site variations in the geometry of the paramagnetic center [48]. The strain values increase with the amount of La doping, thus suggesting gradual structural disordering in YAG: $\mathrm{Ce}^{3+}$ sites. Highly doped samples, which do not contain the YAG crystalline phase, do not exhibit the YAG: $\mathrm{Ce}^{3+}$ EPR signal.

To summarize, EPR analysis provides experimental evidence for the presence of $\mathrm{Ce}^{3+}$ impurities in the investigated samples in $0.03-0.6 \mathrm{La}$ substitution range. $\mathrm{Ce}^{3+}$ incorporates in 
the usual sites of the YAG matrix, however distortions in the local structure occur by increased addition of La. If the level of La doping exceeds 0.6, the EPR signal associated with YAG: $\mathrm{Ce}^{3+}$ vanishes, which is in correlation with XRD and NMR results.

It seems that additionally co-doped $\mathrm{Y}_{3-\mathrm{x}} \mathrm{La}_{\mathrm{x}} \mathrm{Al}_{5} \mathrm{O}_{12}$ compound could be a promising material for the application in the optical thermometry area. By varying the concentration of $\mathrm{La}^{3+}$ ion, various intensities of upconversion luminescence can be easily achieved [49-51]. Also, the emission in different ranges could be improved by appropriate dual doping [52].

\section{Conclusions}

In this work $\mathrm{Y}^{3+}$ substitution by $\mathrm{La}$ in $\mathrm{Y}_{3-\mathrm{x}} \mathrm{La}_{\mathrm{x}} \mathrm{Al}_{5} \mathrm{O}_{12}$ garnet synthesized by sol-gel method has been investigated. It was concluded from the XRD data that substitution of yttrium by samarium with formation of monophasic $\mathrm{Y}_{3-\mathrm{x}} \mathrm{La}_{\mathrm{x}} \mathrm{Al}_{5} \mathrm{O}_{12}$ is possible only at low concentration of lanthanum. The single-phase $\mathrm{Y}_{3-\mathrm{x}} \mathrm{La}_{\mathrm{x}} \mathrm{Al}_{5} \mathrm{O}_{12}$ garnet has been obtained in the cases with $\mathrm{x}=$ $0.03,0.015$ and 0.30 . The lattice parameter $a$ and cell volume $V$ of these samples monotonically increased from $a=12.012 \AA$ and $V=1733.2 \AA$ (for $\mathrm{x}=0$ ) till $a=12.160 \AA$ and $V=1798.1 \AA$ (for $\mathrm{x}=0.30$ ) confirming that larger lanthanum ion enters yttrium position in the garnet. With further increasing of lanthanum $(x=0.45$ and 0.60$)$ the mixtures of garnet and perovskite crystalline phases have formed. In the cases of $\mathrm{Y}_{3-\mathrm{x}} \mathrm{La}_{\mathrm{x}} \mathrm{Al}_{5} \mathrm{O}_{12}$ with $\mathrm{x}=0.75$, 1.0 and 1.50 the formation only perovskite phases were detected. The structural transformations, the region of coexisting phases, the appearance of perovskite-like phases and the residual of garnet phase have been evidently deduced from the results of solid state NMR spectroscopy. Surprisingly, the emission spectra of $\mathrm{Y}_{3-\mathrm{x}} \mathrm{La}_{\mathrm{x}} \mathrm{Al}_{5} \mathrm{O}_{12}$ garnets under $450 \mathrm{~nm}$ excitation consisted of a single broad bands peaked at around $560 \mathrm{~nm}$ originated from d-f transition in $\mathrm{Ce}^{3+}$. The EPR analysis provided experimental evidence for the presence of $\mathrm{Ce}^{3+}$ impurities in the investigated samples in 0.03-0.6 La substitution range. Surprisingly, it was 
determined that lanthanum oxide which was used as lanthanum source contained about $5 \mathrm{ppm}$ of cerium.

\section{Acknowledgments}

This work was supported by a Research grant NEGEMAT (No. S-MIP-19-59) from the Research Council of Lithuania.

\section{The conflict of interest statement}

The work described has not been published before, it is not under consideration for publication anywhere else and does not contain conflict of interest.

\section{References}

[1] R. Skaudzius, D. Enseling, M. Skapas, A. Selskis, E. Pomjakushina, T. Juestel, A. Kareiva and C. Ruegg, Europium-enabled luminescent single crystal and bulk YAG and YGG for optical imaging. Optic. Mater. 60 (2016) 467-473.

[2] D. Sedmidubsky, V. Jakes, K. Rubesova, P. Nekvindova, T. Hlasek, R. Yatskiv, P. Novak, Magnetism and optical properties of $\mathrm{Yb}_{3} \mathrm{Al}_{5} \mathrm{O}_{12}$ hosted $\mathrm{Er}^{3+}$ - experiment and theory. $\mathrm{J}$. All. Cmpd. 810 (2019) Art. No.: UNSP 151903.

[3] L. Pavasaryte, A. Katelnikovas, A. Momot, G. Reekmans, A. Hardy, M. Van Bael, P. Adriaensens, T.C.K. Yang and A. Kareiva. $\mathrm{Eu}^{3+}-$ doped $\mathrm{Ln}_{3} \mathrm{Al}_{5} \mathrm{O}_{12}(\mathrm{Ln}=\mathrm{Er}, \mathrm{Tm}, \mathrm{Yb}, \mathrm{Lu})$ garnets: Synthesis, characterization and investigation of structural and luminescence properties. J. Lumin. 212 (2019) 14-22.

[4] M. Skruodiene, A. Katelnikovas, L. Vasylechko, R. Skaudzius, $\mathrm{Tb}^{3+}$ to $\mathrm{Cr}^{3+}$ energy transfer in a co-doped $\mathrm{Y}_{3} \mathrm{Al}_{5} \mathrm{O}_{12}$ host. J. Lumin. 208 (2019) 327-333.

[5] M. Michalkova, J. Kraxner, M. Michalek, D. Galusek, Preparation of translucent YAG glass/ceramic at temperatures below 900 degrees C. J. Eur. Ceram. Soc. 40 (2020) 2581-2585. 
[6] M.A. Almomani, M.I. Al-Widyan, S.M. Mohaidat, Thermal shock resistance of yttrium aluminium oxide $\mathrm{Y}_{3} \mathrm{Al}_{5} \mathrm{O}_{12}$ thermal barrier coating for titanium alloy. J. Mechan. Eng. Sci. 14 (2020) 6514-6525.

[7] A. Katelnikovas, T. Justel, D. Uhlich, J.-E. Jorgensen, S. Sakirzanovas, A. Kareiva, Chem. Eng. Comm. 195 (2008) 758-769.

[8] M.M. Xu, Z.J. Zhang, J.T. Zhao, J.Z. Zhang, Z.W. Liu, J. All. Compd. 647 (2015) 10751080.

[9] J. Livage, M. Henry, C. Sanchez, Sol-gel chemistry of transition metal oxides. Progr. Solid State Chem. 18 (1988) 259-342.

[10] C. J. Brinker, G. W. Scherrer, Sol-gel science: the physics and chemistry of sol-gel processing, Academic Press, New York, 1990.

[11] B.L. Cushing, V.L. Kolesnichenko, C.J. O`Connor, Recent advances in the liquid-phase syntheses of inorganic nanoparticles. Chem. Rev. 104 (2004) 3893-3946.

[12] J.D. Mackenzie, E.P. Bescher, Chemical routes in the synthesis of nanomaterials using the sol-gel process. Acc. Chem. Res. 40 (2007) 810-818.

[13] K. Ishikawa, E. Garskaite, A. Kareiva, Sol-gel synthesis of calcium phosphate-based biomaterials - A review of environmentally benign, simple and effective synthesis routes. J. Sol-Gel Sci. Technol. 94 (2020) 551-572.

[14] N. Dubnikova, E. Garskaite, J. Pinkas, P. Bezdicka, A. Beganskiene, A. Kareiva, Sol-gel preparation of selected lanthanide aluminium garnets. J. Sol-Gel Sci. Techn. 55 (2010) 213219.

[15] N. Dubnikova, E. Garskaite, R. Raudonis, A. Kareiva, Neodymium substitution effects in sol-gel derived $\mathrm{Y}_{3-\mathrm{x}} \mathrm{Nd}_{\mathrm{x}} \mathrm{Al}_{5} \mathrm{O}_{12}$. Mater. Chem. Phys. 137 (2012) 660-664.

[16] R. Skaudzius, S. Sakirzanovas, A. Kareiva, On the samarium substitution effects in $Y_{3-}$ ${ }_{\mathrm{x}} \mathrm{Sm}_{\mathrm{x}} \mathrm{Al}_{5} \mathrm{O}_{12}(\mathrm{x}=$ 0.1-3.0). J. Electron. Mater. 47 (2018) 3951-3956. 
[17] E. Garskaite, N. Dubnikova, A. Katelnikovas, J. Pinkas, A. Kareiva, Syntheses and characterisation of $\mathrm{Gd}_{3} \mathrm{Al}_{5} \mathrm{O}_{12}$ and $\mathrm{La}_{3} \mathrm{Al}_{5} \mathrm{O}_{12}$ garnets. Collect. Czech. Chem. Commun. 72 (2007) 321-333.

[18] R. Skaudzius, A. Zalga, A. Kareiva, Sol-gel synthesis of nanocrystalline $\mathrm{LaAlO}_{3}-\mathrm{M}_{2} \mathrm{O}_{3}$ $(\mathrm{M}=\mathrm{La}, \mathrm{Al})$ and $\mathrm{Nd}: \mathrm{LaAlO}_{3}-\mathrm{M}_{2} \mathrm{O}_{3}$ composite materials via ,phase metathesis“ route. Materials Science (Medžiagotyra). 14 (2008) 193-197.

[19] L. Pavasaryte, A. Katelnikovas, V. Klimavicius, V. Balevicius, A. Krajnc, G. Mali, J. Plavec, A. Kareiva, Eu ${ }^{3+}$-Doped $\mathrm{Y}_{3-x} \mathrm{Nd}_{x} \mathrm{Al}_{5} \mathrm{O}_{12}$ garnet: synthesis and structural investigation. Phys. Chem. Chem. Phys. 19 (2017) 3729-3737.

[20] L. Pavasaryte, A. Katelnikovas, V. Klimavicius, V. Balevicius, A. Momot, M. Van Bael, A. Hardy, A. Kareiva, Eu ${ }^{3+}$-Doped $\mathrm{Y}_{3-\mathrm{x}} \mathrm{Sm}_{\mathrm{x}} \mathrm{Al}_{5} \mathrm{O}_{12}$ garnet: synthesis and structural investigation. New J. Chem. 42 (2018) 2278-2287.

[21] S. Stoll, A. Schweiger, EasySpin, a comprehensive software package for spectral simulation and analysis in EPR. J. Magn. Reson. 178 (2006) 42-55.

[22] M. Misevicius, L. Dagys, A. Maršalka, K. Kristinaityte, V. Balevicius, ${ }^{27}$ Al MAS NMR spectroscopy study of $\mathrm{Eu}^{2+}$-doped and $\mathrm{Dy}^{3+}$-co-doped $\mathrm{SrAl}_{4} \mathrm{O}_{7}$. Lith. J. Phys. 60 (2020) 91-98. [23] S. Alahraché, M. Deschamps, J. Lambert, M.R. Suchomel, D. De Sousa Meneses, G. Matzen, D. Massiot, E. Véron, M. Allix, Crystallization of $\mathrm{Y}_{2} \mathrm{O}_{3}-\mathrm{Al}_{2} \mathrm{O}_{3}$ Rich Glasses: Synthesis of YAG Glass-Ceramics. J. Phys. Chem. C 115 (2011) 20499-20506.

[24] L.S. Du, J.F. Stebbins, Calcium and Strontium Hexaluminates: NMR Evidence that "Pentacoordinate" Cation Sites Are Four-Coordinated. J. Phys. Chem. B 108 (2004) 36813685 .

[25] S.R. Jansen, H.T. Hintzen, R. Metselaar, J.W. de Haan, L.J.M. van de Ven, A.P.M. Kentgens, G.H. Nachtegaal, Multiple Quantum ${ }^{27}$ Al Magic-Angle-Spinning Nuclear Magnetic Resonance Spectroscopic Study of $\operatorname{SrAl}_{12} \mathrm{O}_{19}$ : Identification of a ${ }^{27} \mathrm{Al}$ Resonance from a WellDefined $\mathrm{AlO}_{5}$ Site. J. Phys. Chem. B 102 (1998) 5969-5976. 
[26] K. Harindranath, K. Anusree Viswanath, C. Vinod Chandranb, T. Bräuniger, P.K. Madhuc, T.G. Ajithkumar, P.A. Joy, Evidence for the co-existence of distorted tetrahedral and trigonal bipyramidal aluminum sites in $\mathrm{SrAl}_{12} \mathrm{O}_{19}$ from ${ }^{27} \mathrm{Al}$ NMR studies. Solid State Commun. 150 (2010) 262-266.

[27] N.W. Thomas, Crystal structure-physical property relationships in perovskites, Acta Cryst. B45 (1989) 337-344.

[28] Z. Zeng, Y. Xu, Z. Zhang, Z. Gao, M. Luo, Z. Yin, C. Zhang, J. Xu, B. Huang, F. Luo, Y. Du, C. Yan, Rare-earth-containing perovskite nanomaterials: design, synthesis, properties and applications. Chem. Soc. Rev. 49 (2020) 1109-1143.

[29] M.F. Reid, Theory of rare-earth electronic structure and spectroscopy. In.: Handbook on the Physics and Chemistry of Rare Earths / Ed. J.C.G. Bunzli, V.K. Pecharsky, 50 (2016) 47 64.

[30] Y. Suffren, O. Leynaud, P. Plaindoux, A. Brenier, I. Gautier-Luneau, Differences and similarities between lanthanum and rare-earth iodate anhydrous polymorphs: Structures, thermal behaviors, and luminescent properties. Inorg. Chem. 55 (2016) 11264-11272.

[31] P.A. Nagpure, N.S. Bajaj, R.P. Sonekar, S.K. Omanwar, Synthesis and luminescence studies of novel rare earth activated lanthanum pentaborate. Ind. J. Pure Appl. Phys. 49 (2011) 799-802.

[32] A. Kruk, J. Polnar, Investigation on the physicochemical properties of La-doped $\mathrm{Er}_{0.05} \mathrm{Y}_{1.95} \mathrm{O}_{3}$ nanopowders. J. Therm. Anal. Calorim. 139 (2020) 765-773.

[33] G.Q. Wang, B.W. Liu, Y.P. Lin, Y. Shi, R. Ye, L.Y. Li, Color-tunable upconversion luminescence in novel lanthanum borogermanates for optical thermometry application. J. All. Cmpd. 826 (2020) Art. No.: 153274.

[34] M. Colmont, P. Boutinaud, C. Latouche, F. Massuyeau, M. Huve, A. Zadoya, S. Jobic, Origin of luminescence in $\mathrm{La}_{2} \mathrm{MoO}_{6}$ and $\mathrm{La}_{2} \mathrm{Mo}_{2} \mathrm{O}_{9}$ and their Bi-doped variants. Inorg. Chem. 59 (2020) 3215-3220. 
[35] M. Freeda, T.D. Subash, Comparision of photoluminescence studies of lanthanum, terbium doped calcium cluminate nanophosphors $\left(\mathrm{CaAl}_{2} \mathrm{O}_{4}: \mathrm{La}, \mathrm{CaAl}_{2} \mathrm{O}_{4}: \mathrm{Tb}\right)$ by sol-gel method. Mater. Today: Proceed. 4 (2017) 4302-4307.

[36] A. Katelnikovas, S. Sakirzanovas, D. Dutczak, J. Plewa, D. Enseling, H. Winkler, A. Kareiva, T. Jüstel, Synthesis and optical properties of yellow emitting garnet phosphors for pcLEDs. J. Lumin. 136 (2013) 17-25.

[37] Z. Zhou, N. Zhou, X. Lu, M. Kate, D. Valdesueiro, J.R. van Ommen, H.T. (Bert) Hintzend, Performance improvement by alumina coatings on $\mathrm{Y}_{3} \mathrm{Al}_{5} \mathrm{O}_{12}: \mathrm{Ce}^{3+}$ phosphor powder deposited using atomic layer deposition in a fluidized bed reactor. RSC Adv. 6 (2016) 76454 76462

[38] A. Katelnikovas, T. Bareika, P. Vitta, T. Jüstel, H. Winkler, A. Kareiva, A. Zukauskas, G. Tamulaitis, $\mathrm{Y}_{3-\mathrm{x}} \mathrm{Mg}_{2} \mathrm{AlSi}_{2} \mathrm{O}_{12}: \mathrm{Ce}_{\mathrm{x}}{ }^{3+}$ phosphors - prospective for warm-white light emitting diodes. Opt. Mater. 32 (2010) 1261-1265.

[39] H. Nakamura, K. Shinozaki, T. Okumura, K. Nomura, T. Akai, Massive red shift of Ce $\mathrm{Ce}^{3+}$ in $\mathrm{Y}_{3} \mathrm{Al}_{5} \mathrm{O}_{12}$ incorporating super-high content of Ce. RSC Adv. 10 (2020) 12535-12546.

[40] Y. Jia, Y. Huang, N. Guo, H. Qiao, Y. Zheng, W. Lv, Q. Zhao, H. You, $\mathrm{Mg}_{1.5} \mathrm{Lu}_{1.5} \mathrm{Al}_{3.5} \mathrm{Si}_{1.5} \mathrm{O}_{12}: \mathrm{Ce}^{3+}, \mathrm{Mn}^{2+}$ : A novel garnet phosphor with adjustable emission color for blue light-emitting diodes. RSC Adv. 2 (2012) 2678-2681.

[41] H.R. Lewis, Paramagnetic resonance of $\mathrm{Ce}^{3+}$ in yttrium aluminum garnet. J. Appl. Phys. 37 (1966) 739-741.

[42] G.R. Asatryan, D.D. Kramushchenko, Y.A. Uspenskaya, P.G. Baranov, A.G. Petrosyan, Family of paramagnetic centers of $\mathrm{Ce}^{3+}$ ions in yttrium aluminum garnet. Phys. Solid State. 56 (2014) 1150-1156.

[43] D. V. Azamat, V. V. Belykh, D.R. Yakovlev, F. Fobbe, D.H. Feng, E. Evers, L. Jastrabik, A. Dejneka, M. Bayer, Electron spin dynamics of $\mathrm{Ce}^{3+}$ ions in YAG crystals studied by pulseEPR and pump-probe Faraday rotation. Phys. Rev. B. 96 (2017) 1-10. 
[44] E. V. Edinach, Y.A. Uspenskaya, A.S. Gurin, R.A. Babunts, H.R. Asatryan, N.G. Romanov, A.G. Badalyan, P.G. Baranov, Electronic structure of non-Kramers $\mathrm{Tb}^{3+}$ centers in garnet crystals and evidence of their energy and spin transfer to $\mathrm{Ce}^{3+}$ emitters. Phys. Rev. B. 100 (2019) 1-14.

[45] W. Zhang, T. Lu, N. Wei, B. Ma, F. Li, Z. Lu, J. Qi, Effect of annealing on the optical properties of Nd:YAG transparent ceramics. Opt. Mater. 34 (2012) 685-690.

[46] L. Rimai, T. Kushida, Paramagnetic resonance of $\mathrm{Fe}^{3+}$ in yttrium aluminum, lutetium aluminum, and lutetium gallium garnets. Phys. Rev. 143 (1966) 160-164.

[47] C.Y. Chen, G.J. Pogatshnik, Y. Chen, M.R. Kokta, Optical and electron paramagnetic resonance studies of $\mathrm{Fe}$ impurities in yttrium aluminum garnet crystals. Phys. Rev. B. 38 (1988) 8555-8561.

[48] S. Stoll, CW-EPR Spectral Simulations: Solid State. Methods Enzymol. 563 (2015) 121142.

[49] E. Garskaite, M. Lindgren, M.-A. Einarsrud, T. Grande, Luminescent properties of rare earth $(\mathrm{Er}, \mathrm{Yb})$ doped yttrium aluminium garnet thin films and bulk samples synthesised by an aqueous sol-gel technique. J. Eur. Ceram. Soc. 30 (2010) 1707-1715.

[50] Y. Liu, G.X. Bai, E. Pan, Y.J. Hua, L. Chen, S.Q. Xu, Upconversion fluorescence property of $\mathrm{Er}^{3+} / \mathrm{Yb}^{3+}$ codoped lanthanum titanate microcrystals for optical thermometry. J. All. Cmpd. 822 (2020) 153449.

[51] T. Vairapperumal, M. Lakshmi, R.V. Kumar, S.K. Janardhanan, M.A. Kumar, Dual mode luminescence from lanthanum orthovanadate nanoparticles. J. Lumin. 217 (2020) 116761.

[52] C. Zhao, D. Zhu, M. Ma, T. Han, M. Tu, Brownish red emitting YAG:Ce ${ }^{3+}, \mathrm{Cu}^{+}$ phosphors for enhancing the color rendering index of white LEDs. J. All. Cmpd. 523 (2012) $151-154$ 
Institute of Solid State Physics, University of Latvia as the Center of Excellence has received funding from the European Union's Horizon 2020 Framework Programme H2020-WIDESPREAD-01-2016-2017-TeamingPhase2 under grant agreement No. 739508, project CAMART2 


\section{Figure Captions}

Fig. 1. XRD patterns of sol-gel derived $\mathrm{Y}_{3-\mathrm{x}} \mathrm{La}_{\mathrm{x}} \mathrm{Al}_{5} \mathrm{O}_{12}$ samples.

Fig. 2. ${ }^{27} \mathrm{Al}$ MAS NMR spectra of the $\mathrm{Y}_{3-\mathrm{x}} \mathrm{La}_{\mathrm{x}} \mathrm{Al}_{5} \mathrm{O}_{12}$ samples. The spinning sidebands from $\mathrm{Al}^{\mathrm{VI}}$ sites are denoted by asterisks.

Fig. 3. The monitoring of structural evolution in $\mathrm{Y}_{3-\mathrm{x}} \mathrm{La}_{\mathrm{x}} \mathrm{Al}_{5} \mathrm{O}_{12}$ using the normalized integral intensities $\mathrm{Y}-\mathrm{Al}^{\mathrm{VI}} /\left(\mathrm{Y}-\mathrm{Al}^{\mathrm{VI}}+\mathrm{La}-\mathrm{Al}^{\mathrm{VI}}\right)$ and $\mathrm{La}-\mathrm{Al}^{\mathrm{VI}} /\left(\mathrm{Y}-\mathrm{Al}^{\mathrm{VI}}+\mathrm{La}-\mathrm{Al}^{\mathrm{VI}}\right)$ (red and green points, respectively) as function of concentration of $\mathrm{La}^{3+}$ in the samples. The overlapped contours were separated using a multiple Voigt profile fitting.

Fig. 4. SEM micrographs of $\mathrm{Y}_{3-\mathrm{x}} \mathrm{La}_{\mathrm{x}} \mathrm{Al}_{5} \mathrm{O}_{12}$ samples with different amount of lanthanum: $\mathrm{x}=$ 0.15 (bottom, left), $x=0.3$ (bottom, right), $x=0.45$ (middle, left), $x=0.6$ (middle, right), $x=$ 0.75 (top, left) and $x=1.0$ (top, right).

Fig. 5. Excitation (top) and emission (bottom) spectra of $\mathrm{Y}_{1-\mathrm{x}} \mathrm{La}_{\mathrm{x}} \mathrm{Al}_{5} \mathrm{O}_{12}$ samples.

Fig. 6. EPR spectra of the investigated $\mathrm{Y}_{1-\mathrm{x}} \mathrm{La}_{\mathrm{x}} \mathrm{Al}_{5} \mathrm{O}_{12}$ samples having different substitutional level $\mathrm{x}$.

Fig. 7. Assignment of $\mathrm{Fe}^{3+}$ and $\mathrm{Ce}^{3+}$ impurity EPR signals. 
Graphical Abstract (for review)

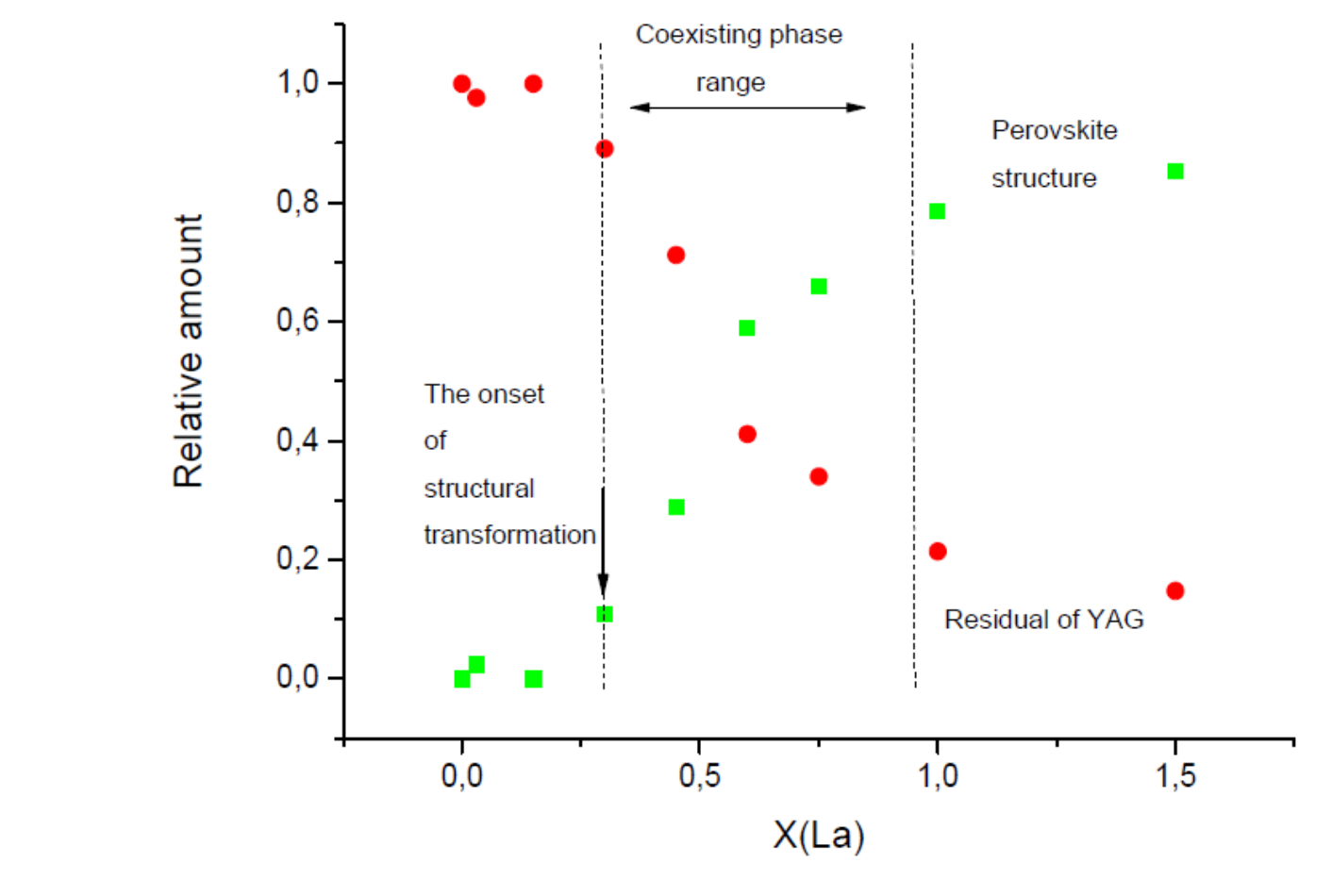

\section{Graphical Abstract (for review)}

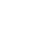

X(La) 


\section{Highlights}

$>\mathrm{Y}_{3-\mathrm{x}} \mathrm{La}_{\mathrm{x}} \mathrm{Al}_{5} \mathrm{O}_{12}$ specimens were synthesized using aqueous sol-gel synthesis method.> Monophasic garnets obtained at low substitution of yttrium by lanthanum. > The region of coexisting phases have been evidently deduced by solid state NMR spectroscopy. > The $\mathrm{Ce}^{3+}$ emission at around 560 nm was observed in $\mathrm{Y}_{3-\mathrm{x}} \mathrm{La}_{\mathrm{x}} \mathrm{Al}_{5} \mathrm{O}_{12}$ garnets. > The EPR analysis provided experimental evidence for the presence of $\mathrm{Ce}^{3+}$ impurities in the samples. 
Table 1. SH parameter values of the $\mathrm{Ce}^{3+} \mathrm{EPR}$ signal.

\begin{tabular}{c|ccc|ccc}
\hline \multirow{2}{*}{ Sample } & \multicolumn{3}{|c|}{$g$ tensor } & \multicolumn{3}{c}{ strain } \\
\cline { 2 - 7 } & $g_{x} \pm 0.002$ & $g_{y} \pm 0.004$ & $g_{z} \pm 0.002$ & $\Delta g_{x} \pm 0.005$ & $\Delta g_{y} \pm 0.005$ & $\Delta g_{z} \pm 0.003$ \\
\hline La0.03YAG & 2.750 & 1.860 & 0.898 & 0.055 & 0.085 & 0.024 \\
La0.15YAG & 2.770 & 1.845 & 0.891 & 0.065 & 0.100 & 0.031 \\
La0.30YAG & 2.798 & 1.838 & 0.882 & 0.085 & 0.145 & 0.041 \\
La0.45YAG & 2.822 & 1.820 & 0.878 & 0.093 & 0.175 & 0.042 \\
La0.60YAG & 2.820 & 1.848 & 0.877 & 0.140 & 0.220 & 0.050 \\
\hline
\end{tabular}




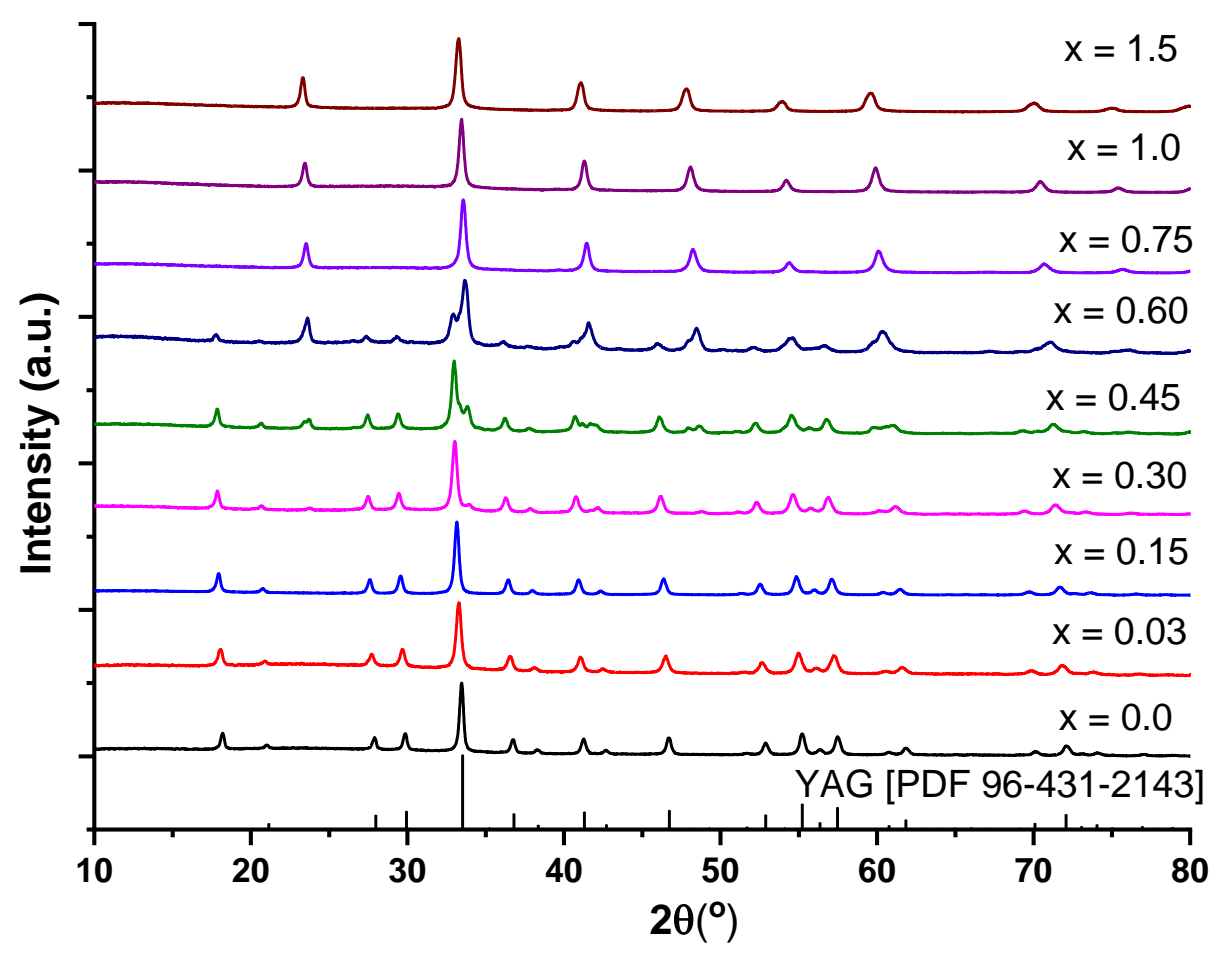

Fig. 1. XRD patterns of sol-gel derived $\mathrm{Y}_{3-\mathrm{x}} \mathrm{La}_{\mathrm{x}} \mathrm{Al}_{5} \mathrm{O}_{12}$ samples. 


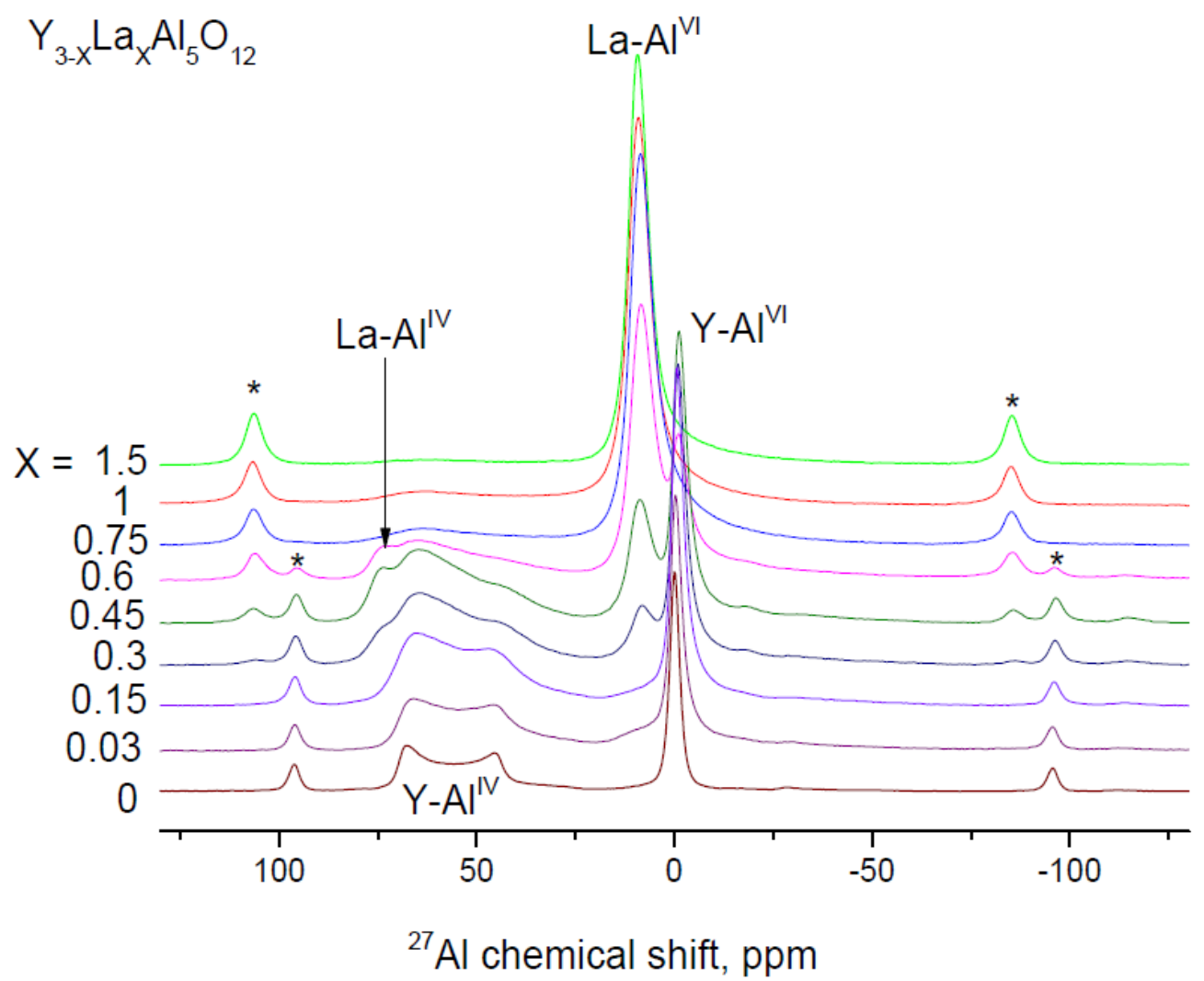

Fig. 2. ${ }^{27} \mathrm{Al}$ MAS NMR spectra of the $\mathrm{Y}_{3-\mathrm{x}} \mathrm{La}_{\mathrm{x}} \mathrm{Al}_{5} \mathrm{O}_{12}$ samples. The spinning sidebands from $\mathrm{Al}^{\mathrm{VI}}$ sites are denoted by asterisks. 


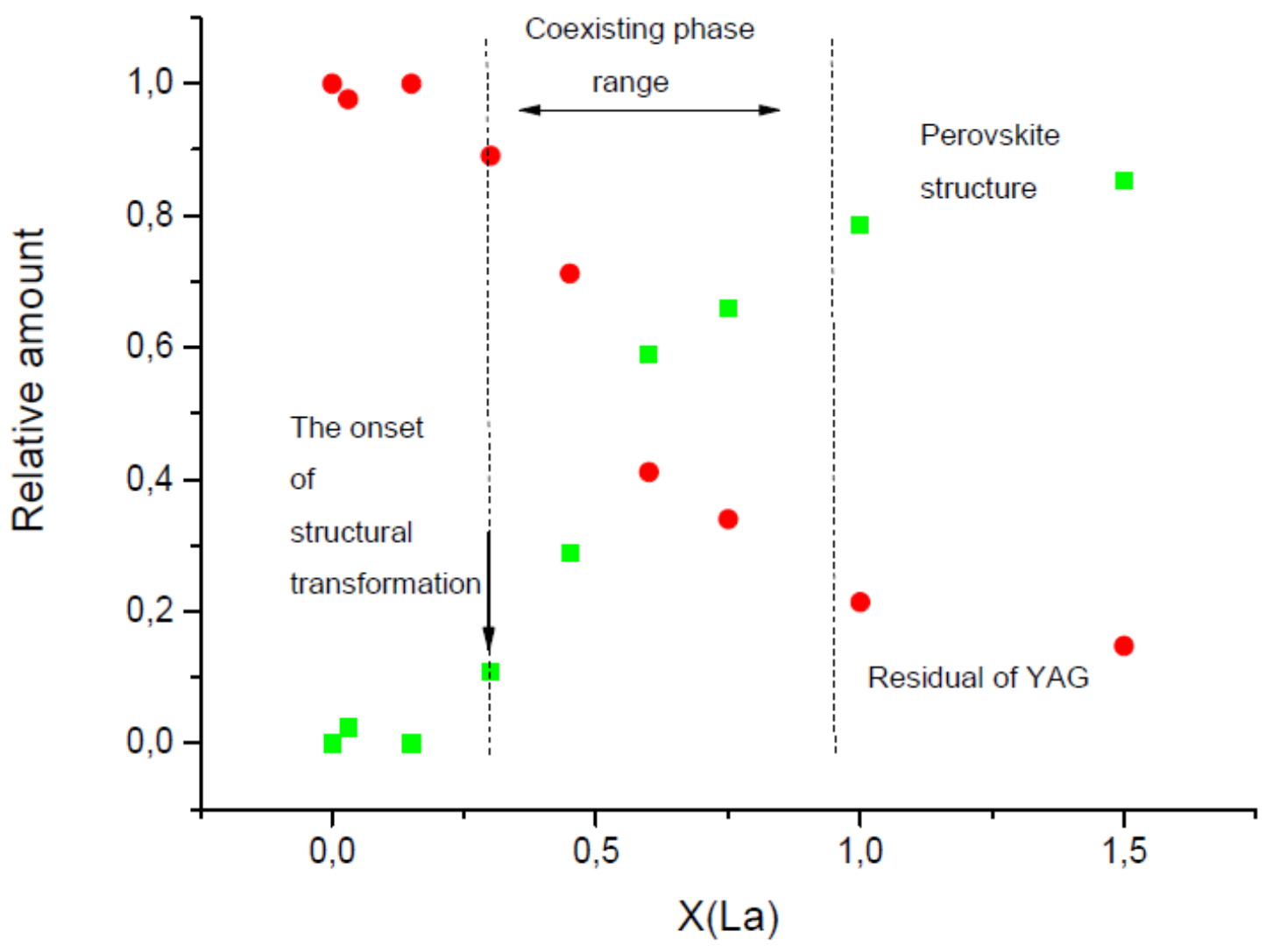

Fig. 3. The monitoring of structural evolution in $\mathrm{Y}_{3-\mathrm{x}} \mathrm{La}_{\mathrm{x}} \mathrm{Al}_{5} \mathrm{O}_{12}$ using the normalized integral intensities $\mathrm{Y}-\mathrm{Al}^{\mathrm{VI}} /\left(\mathrm{Y}-\mathrm{Al}^{\mathrm{VI}}+\mathrm{La}-\mathrm{Al}^{\mathrm{VI}}\right)$ and $\mathrm{La}-\mathrm{Al}^{\mathrm{VI}} /\left(\mathrm{Y}-\mathrm{Al}^{\mathrm{VI}}+\mathrm{La}-\mathrm{Al}^{\mathrm{VI}}\right)$ (red and green points, respectively) as function of concentration of $\mathrm{La}^{3+}$ in the samples. The overlapped contours were separated using a multiple Voigt profile fitting. 

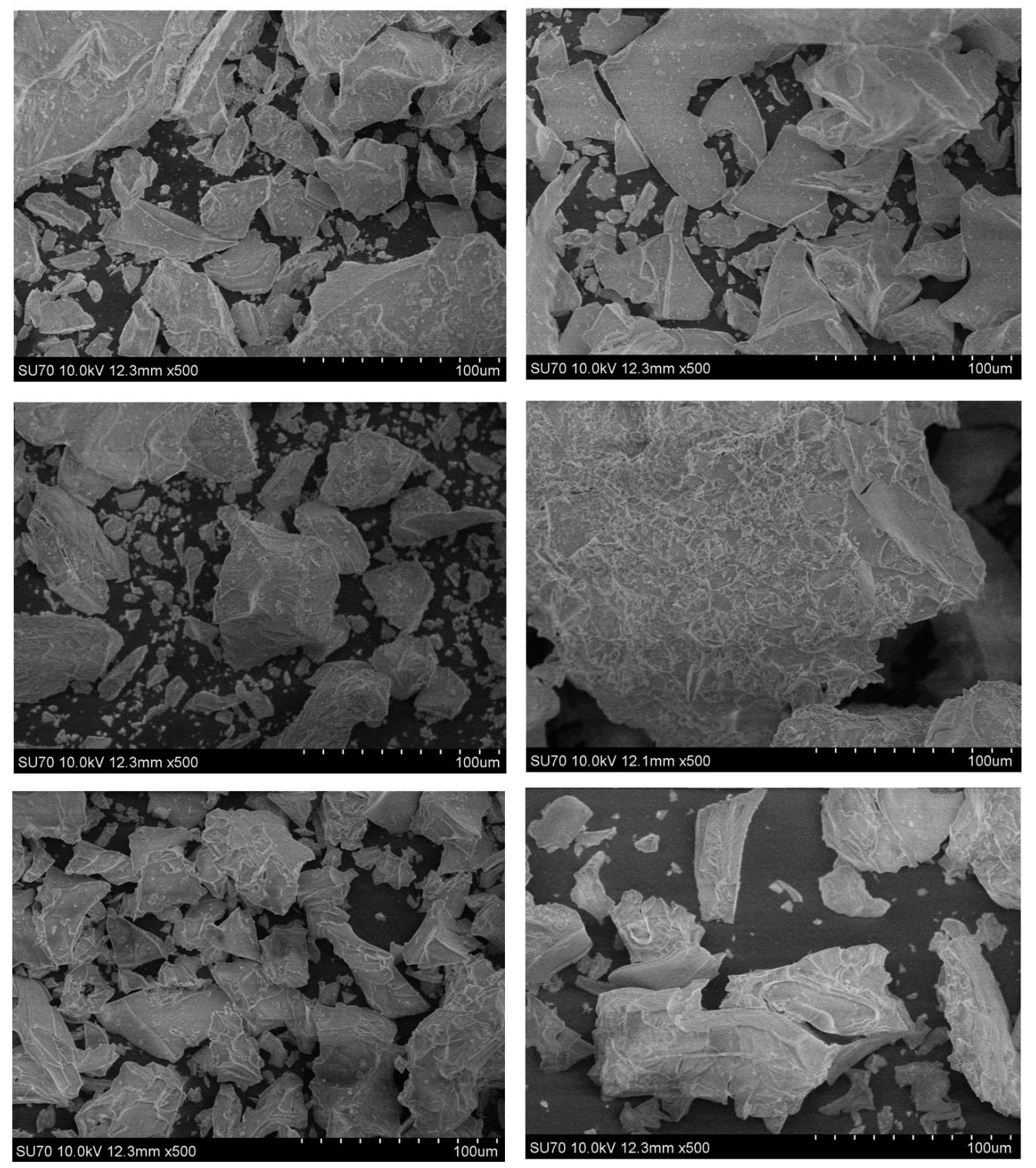

Fig. 4. SEM micrographs of $\mathrm{Y}_{3-\mathrm{x}} \mathrm{La}_{\mathrm{x}} \mathrm{Al}_{5} \mathrm{O}_{12}$ samples with different amount of lanthanum: $\mathrm{x}=0.15$ (bottom, left), $x=0.3$ (bottom, right), $x=0.45$ (middle, left), $x=0.6$ (middle, right), $x=0.75$ (top, left) and $x=1.0$ (top, right). 

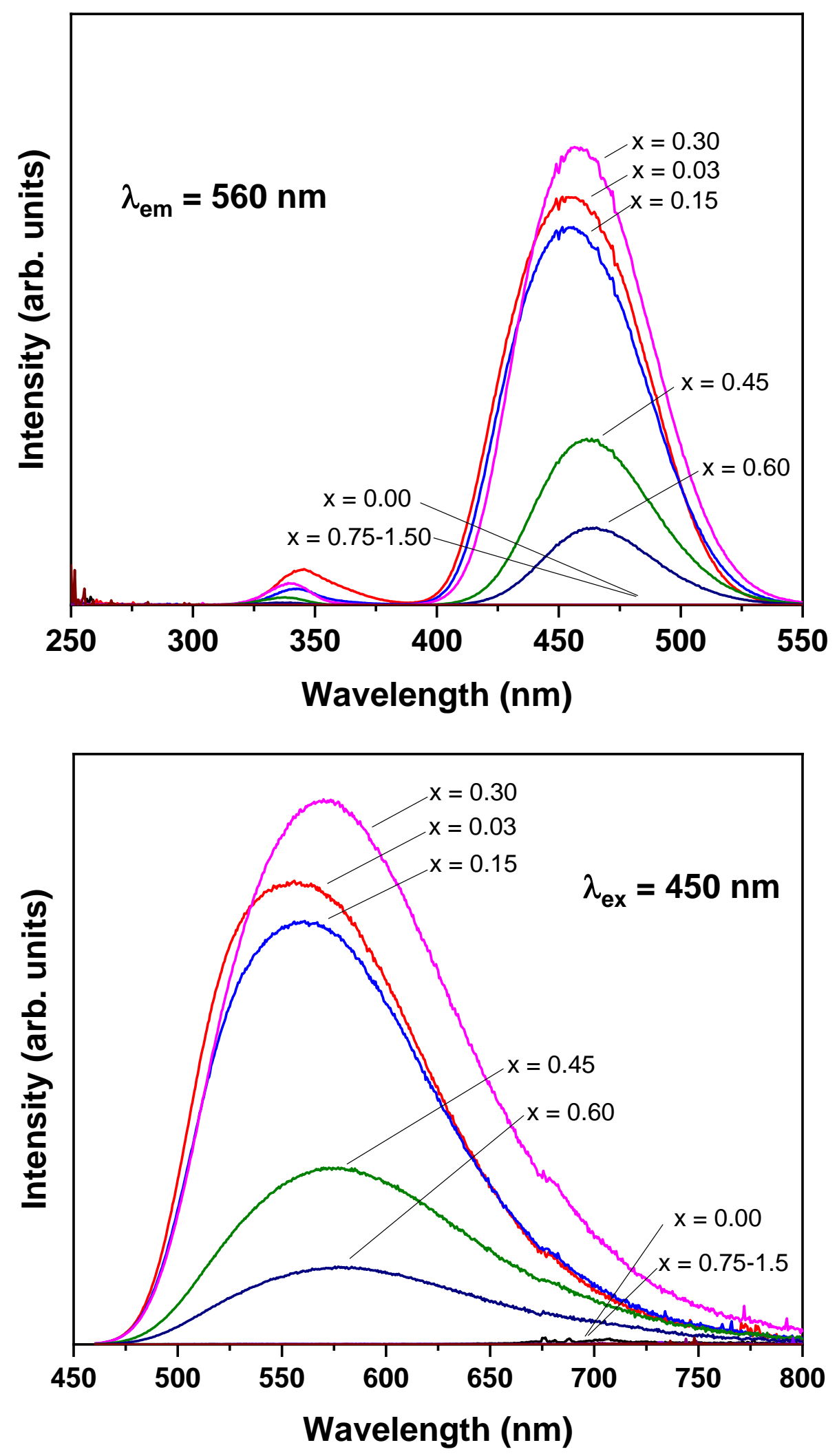

Fig. 5. Excitation (top) and emission (bottom) spectra of $\mathrm{Y}_{1-\mathrm{x}} \mathrm{La}_{\mathrm{x}} \mathrm{Al}_{5} \mathrm{O}_{12}$ samples. 


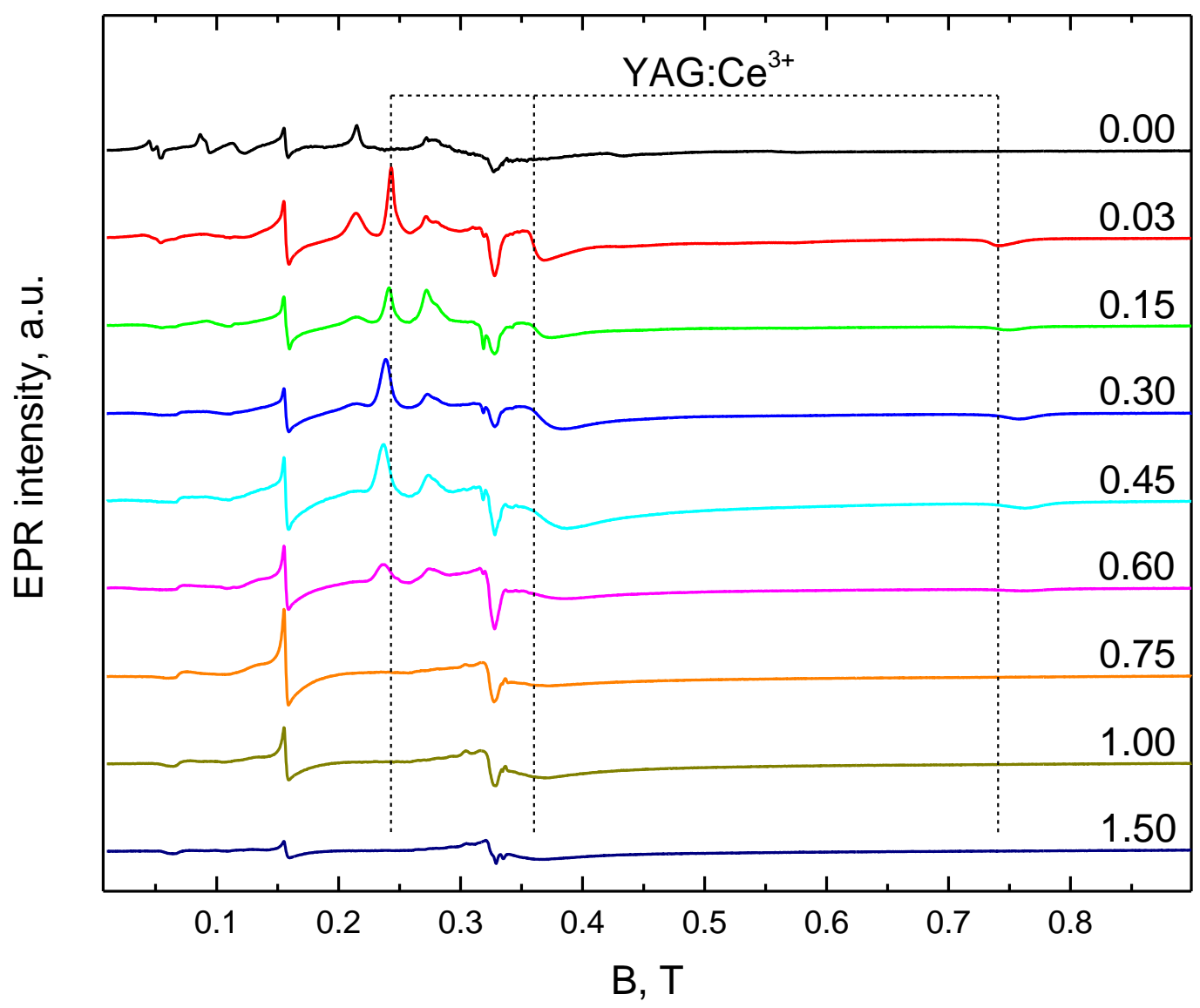

Fig. 6. EPR spectra of the investigated $\mathrm{Y}_{1-\mathrm{x}} \mathrm{La}_{\mathrm{x}} \mathrm{Al}_{5} \mathrm{O}_{12}$ samples having different substitutional level $\mathrm{x}$. 


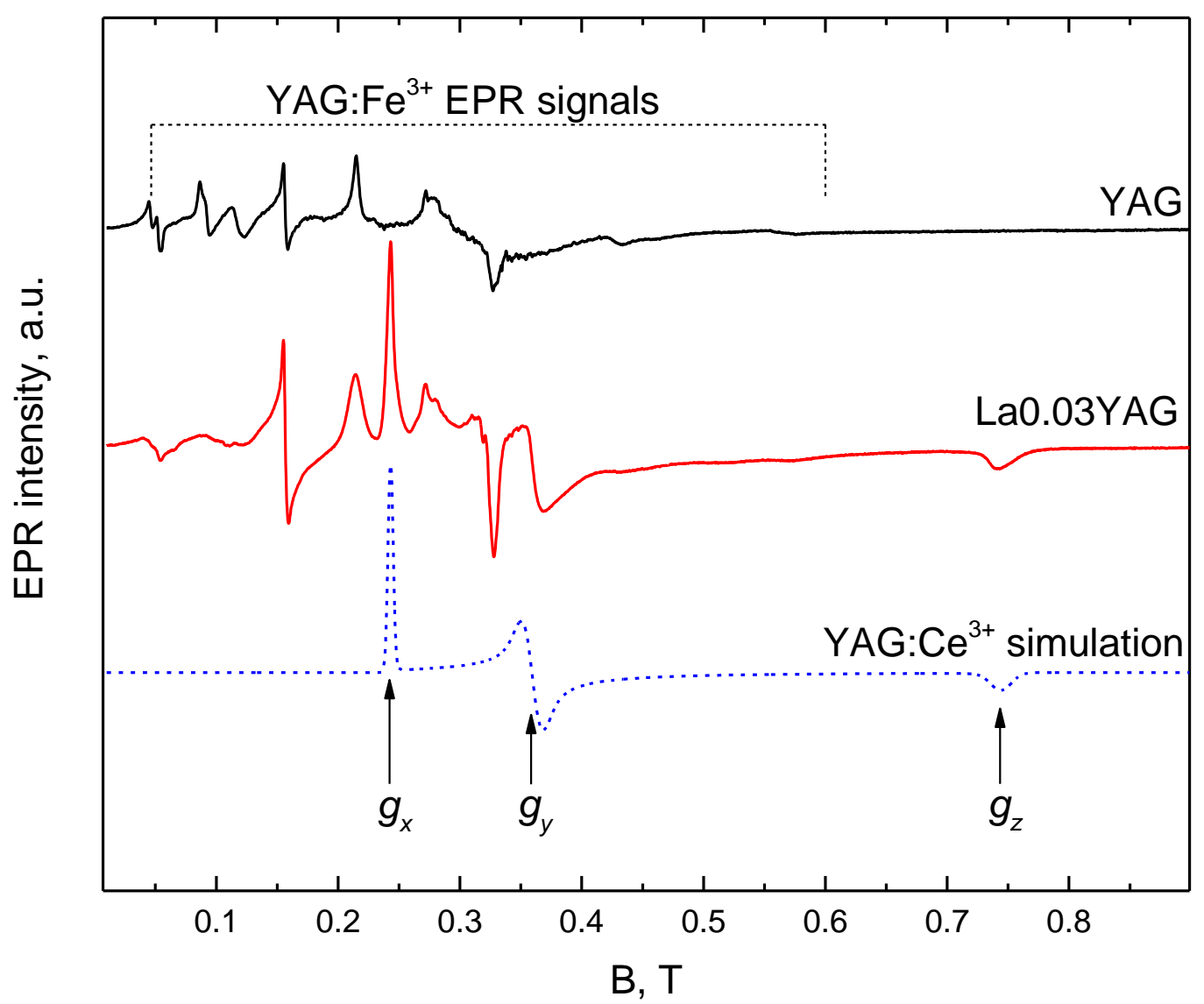

Fig. 7. Assigment of $\mathrm{Fe}^{3+}$ and $\mathrm{Ce}^{3+}$ impurity EPR signals. 
${ }^{\star}$ Declaration of Interest Statement

\section{DECLARATION OF INTEREST}

No conflict of interest was declared. 